DOI: 10.22616/REEP.2019.040

\title{
Career Education as a Set of Planned Actions Integrated in the Study Process
}

\author{
Marite Saulite $^{1}$ Mg. ed.; Rudite Andersone ${ }^{2}$ Dr. paed. \\ University of Latvia, Latvia \\ mmsaulite@inbox.lv11, rudite.andersone@lu.1v²
}

\begin{abstract}
The modern world is becoming more and more complex; everyday there appears and disappears a number of different professions, the employability possibilities change and the role of career education increases because it influences the person's ability to manage successfully the personal life, to learn continuously, to acquire new skills that are necessary in the personal life and professional development. Career development at present is considered a lifelong process not a single concrete episode of choosing the career because the person has to develop creativity and critical thinking, understanding of values and culture, humanism and citizenship, decision-making and problem- solving skills, entrepreneurship and communication skills along with the knowledge, skills needed in the profession and the professional competencies. The development of career management skills becomes more significant. The aim of the study is to explore the development of career management skills in the study process as the basis of career education which is implemented as a set of integrated actions. The study employs the analysis of pedagogical, psychological and career management theories and the results of the empirical research. Empirical research data have been obtained from surveying students and graduates about factors promoting the development of podologists' career management skills and the actions integrated in the study process at the University of Latvia P. Stradins Medical College. The research findings prove that career education is a set of planned actions, which is closely connected with the development of students' professional skills and the formation of sustainable awareness, which is integrated in the study process.
\end{abstract}

Keywords: career education, career management skills, the study process of podologists, university education.

\section{Introduction}

The aim of nowadays education is to realize the link between education and the labour market, especially emphasizing the integrated learning strategy when improving the study process and diversifying the programmes (Cendon, 2018) are activated (Talbot, 2018; Okolie, Yasin, 2017). Thus, career education is integrated also in higher education and new forms for combining theory and practice are sought, paying attention to the development of career management skills that are necessary in personal life and lifelong professional development.

The Education Law of the Republic of Latvia states that career education is measures integrated in the education process in order to ensure the acquisition and development of career management skills of educates, which include being aware of one's interests, abilities and opportunities for selecting the direction of further education and professional career" (Education Law, 2014).

In Latvia, the guidelines on the support system of career development (ELGPN, 2010) underlines that it is possible to develop and promote the career management skills with the help of the support system of career development which is structured by three elements - information for the support of career development, career education and career counselling.

The European guidelines on education (CEDEFOP, 2009; OECD, 2014) emphasize that the acquisition of career management skills has to be integrated effectively in the /individual's/ education process and a link should be ensured between knowledge and those skills that are necessary for work and life actions in general, therefore it is important to improve the study process moving from the acquisition of professional skills to the formation of the individual's professional development as well as to improve the programme in accordance with the transformations of the education paradigm, the needs of the society and orientation to the development of the student's personality paying more attention to the perfection of skills and emphasizing the competences, which are required in the labour market and which need to be acquired during the tertiary studies (European Commission..., 2014).

The present study analyses career education as a set of planned actions integrated in the study process, which ensures the acquisition and development of podologists' career management skills. It is important 
to find out what set of integrated actions that promotes the acquisition of knowledge and skills, which are needed in further career development, including the acquisition of career management skills, in the frame of specialized programmes or programmes integrated in the study process considering the education standards and pedagogical traditions are needed.

Skills are formed in general; they do not need special courses (OECD, 2014), colleges can improve considerably the individual's readiness to learn in his life action changing the approach of teaching/learning aims to the competence and practice-based learning approach, using such methods and strategies /didactic tools/ in the study process that raise the student's self-esteem, facilitate the skill to analyse the personal life experience, to apply it in the acquisition of new knowledge and in development (Jackson, Willis, 2014). Researchers of human pedagogy (Barrett, 2010; Dauber, 2009; Heim, 1998) maintain that the outcome of the study process is the intellectual development of the personality (individual). The basic preconditions of the personality growth and development is active learning that provides a possibility to construct new knowledge according to each individual's previous experience (Stevenson, 2008; Wells, 2001), adjusting it to personal needs and the formation of new skills.

Actually, a curriculum is the planning of the teaching/learning process and the content, the aims of the curricula, in their turn, are closely connected with the societal values. The aim of the study programme "Podology" implemented at the University of Latvia P. Stradins Medical College is to prepare highly qualified, progressively educated, competent and competitive specialists in podology (Ivanova, Saulite, Andersone, 2014; Andersone, 2007).

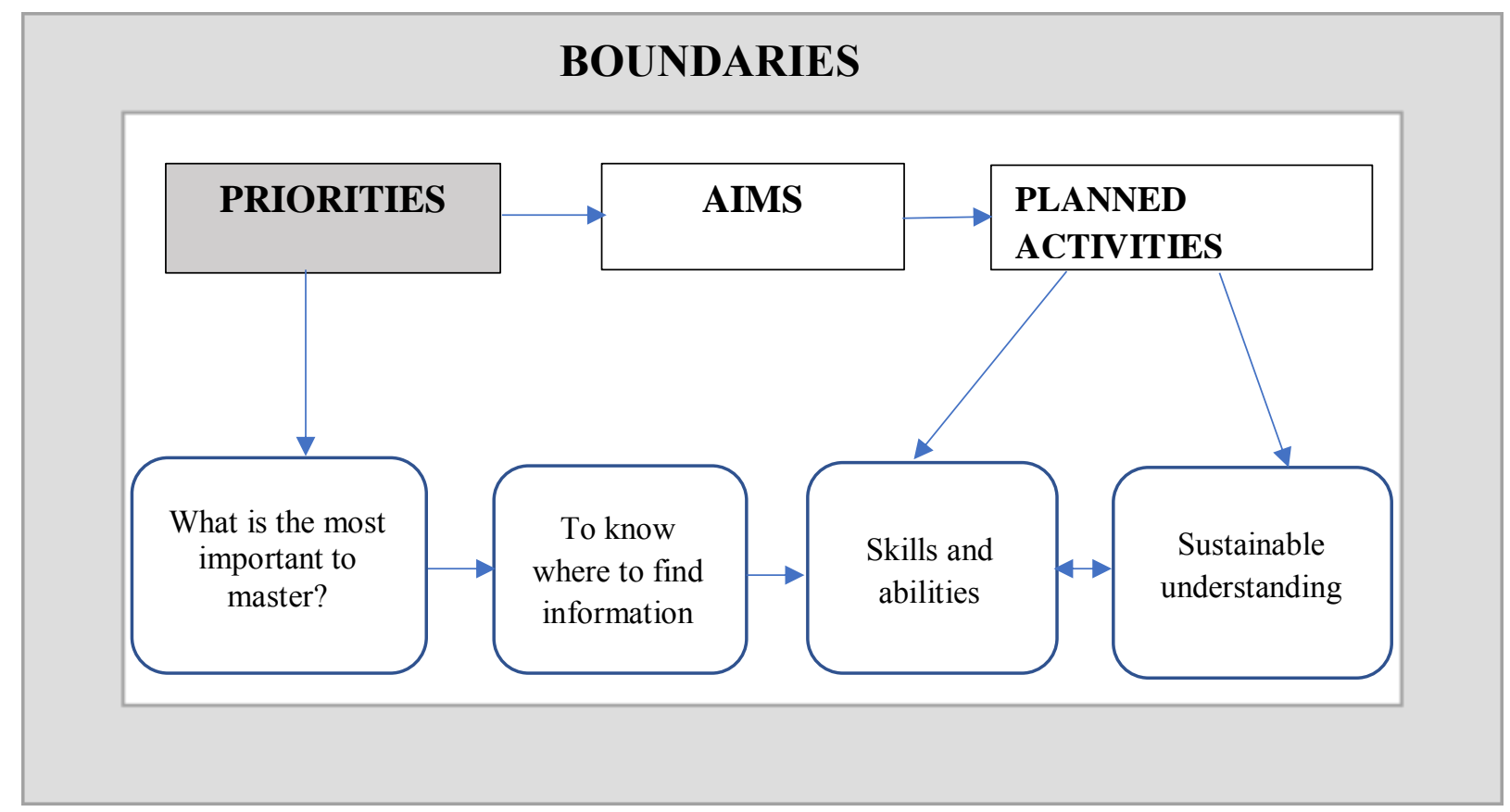

Figure 1. Priorities of the planned activities integrated in the study process in the development of career management skills.

The analysis of pedagogy theories and theoretical study of career education shows that the understanding of teaching/learning develops and changes along with the time. When the social economic conditions change, the approaches and methods in education, including medical education, change, too. Both the academic staff and students develop their awareness about effective learning skills, personalized learning, sustainable knowledge, which one should not only acquire but also be able to apply in life. A student-centred approach is still topical in the practice of tertiary study process; it develops along with the time and is substantiated in pedagogy theory (Huitt, 2011; Fabry, 2012). The courses acquired during the study process serve as a means for developing both students' professional and general skills as well as career management skills, forming the preconditions that activate each individual's personal constructive potential (everything can never be taught!). Thus, such teaching/learning methods, which promote independent, creative actions, e.g., solving of problem situations, group work, research, etc., can be integrated successfully in the study process (Anspoka, Kazaka, 2017). Emphasis should be put also on active learning process in which a student constructs the knowledge corresponding to his 
experience, adjusting it to personal needs and the formation of new skills using the possibilities offered by innovative technologies (Saulite, Koha, 2017). Organizing the study process directed to the development of career management skills, it is important to set the boundaries and to put forward the priorities of the study process (Figure 1).

The aim of the study is to explore the development of career management skills in the study process as the basis of career education which is implemented as a set of integrated actions.

\section{Methodology}

The study employs the analysis of pedagogical, psychological and career management theories and the results of the empirical research. To obtain the quantitative data of the empirical study, a sample of randomly chosen research participants was formed: 50 current students and 50 graduates from the study programme "Podology" implemented at the University of Latvia P. Stradins Medical College.

The questionnaire included five closed-ended questions with a list of possible answers and a possibility to assess the importance of career management skills, individual skills, skills necessary in the development of podologists' career, conditions promoting their development, applied teaching/learning methods and factors defining the development of the career management skills in the study process on the 4-point scale where 4-especially significant, 3- significant, 2-of little significance and $\mathbf{1}$-not significant. Each question ends with the possibility to express freely one's opinion on receiving useful information, attitude and pointof-view about career education as a set of planned activities integrated in the study process which ensure the acquisition and development of career management skills of podologists.

Data were processed using IBM SPSS Statistics Version 22 programme; descriptive statistics and graphic methods, conclusive statistics methods (data validity testing (Cronbach's alpha), central tendency indicators - the Mean, variation indicators - standard deviation and pair correlation analysis applying Spearman's test) were used in the data analysis.

\section{Results and Discussion}

Podologists' opinion on factors promoting the development of career management skills and integrated activities in the study process was explored in the frame of the empirical study. Cronbach's alfa ratio in the graduates' group $(\alpha=0.49)$ indicated that the data of this group had weak suitability while Cronbach's alfa ratio in the students' group $(\alpha=0.67)$ testified about average suitability of data for the analysis. Thus, the obtained findings about factors promoting the development of podologists' career management skills and integrated activities in the study process were analysed only in students' group and are reflected in Figure 2.

Analysing the assessment of factors promoting the development of podologists' career management skills and integrated activities in the study process in students' group it is obvious that students value the highest as the factor promoting the career management skills - the personal maturity (mean 3.52 points, standard deviation 0.54 ), the content of the study programme in general (mean 3.62 points, standard deviation 0.53 ) and qualification practice (mean 3.62 points, standard deviation 0.64 ) as an integrated activity in the study process. Students have given a comparatively unanimous assessment to the college teacher's personal example (mean 3.52 points, standard deviation 0.54 ) as the factor promoting the development of career management skills in the study process. Students' assessment, on the whole, coincides with D. Super's career development theory in which the key concept is career maturity, vocational maturity; it is explained as successful and harmonious career development all through one's life. Other theoreticians on career building (Super, 1963, Chen, 2015, Amundson, 2005) basing on their research also point to changes to which people are subjected in the course of reaching their maturity and are based on the internal need to improve mentally/intellectually as one of the intrinsic individual factors as well as the necessity to acquire and continually supplement one's knowledge and skills caused by external factors, e.g.. the study process and the work environment (qualification practice).

Students have given a relatively ambiguous assessment (mean 3.12 points, standard deviation 0.75 ) to such support activities of career development as career days, meetings with potential employers, events organized by professional associations in the college, etc. that take place parallel to the study process thus acknowledging that career education is a set of actions that need to be integrated in the study process. 


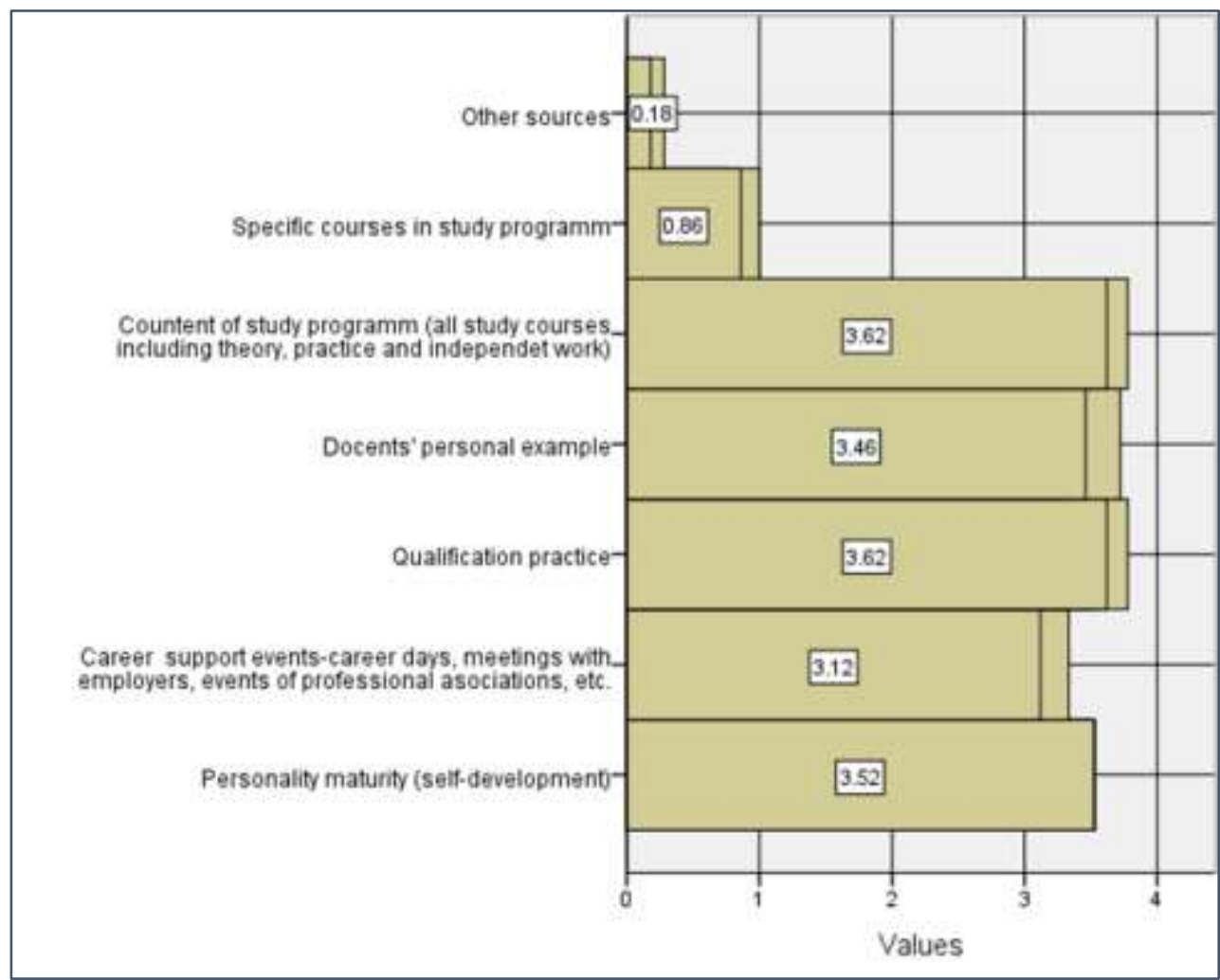

Figure 2. Assessment of factors promoting the development of podologists' career management skills and integrated activities in the study process in students' group.

According to ideas drawn from the theoretical research, the formation of career management skills is closely connected with sustainable knowledge which the person should learn and then be able to apply in practice because the podologists' professional education is not only getting ready for the professional performance but also serves as the basis for lifelong and life-broad learning process. The most important teaching/learning methods that have promoted the development of career management skills according to the graduates' opinion are practical classes (mean 3.88 points, standard deviation 0.33 ) and the solving of non-standard situations (mean 3.72 points, standard deviation 0.50). Students, in their turn, acknowledge the study practice (mean 3.92 points, standard deviation 0.48 ) and practical classes (mean 3.76 points, standard deviation 0.34 ) as the most important. The obtained results (see Figure 3 ) allow concluding that according to research participants' understanding the career management skills are mainly connected with the professional work and development, and the possibility to get closer to the work environment already during the study process when doing the study practice and participating in practical classes and solving different nonstandard clinical cases that create the sense of security and conviction to attain the immediate aims of learning - to obtain education and work.

Both graduates (mean 3.56 points) and students (mean 3.64 points) mark the analysis of situations (cases) as an important teaching/learning method that promotes the development of career management skills, which according to the pedagogical aspects of the development of career management skills and the specifics of the podologists' study process, the experience-based learning approach, help both to reach the aims of learning and to improve the career management skills.

The results of pair correlation analysis using the Spearman's test applied to teaching/learning methods that promote the development of podologists' career management skills as a set of activities integrated in the study process confirm a statistically significant link $\left(\mathrm{r}_{\mathrm{s}}=0.57, \mathrm{p}<0.001\right)$ between the analysis of situations and solving of non-standard situations. The results of the analysis concerning the teaching/learning methods that promote the development of podologists' career management skills need to be taken into consideration in the improvement of podologists' study process in order to ensure the integration of career education in the study process along with the aim and content of the study programme supplementing it with such teaching/learning methods and activities that would form the perspective of sustainable development in the acquisition of podologists' career management skills. 


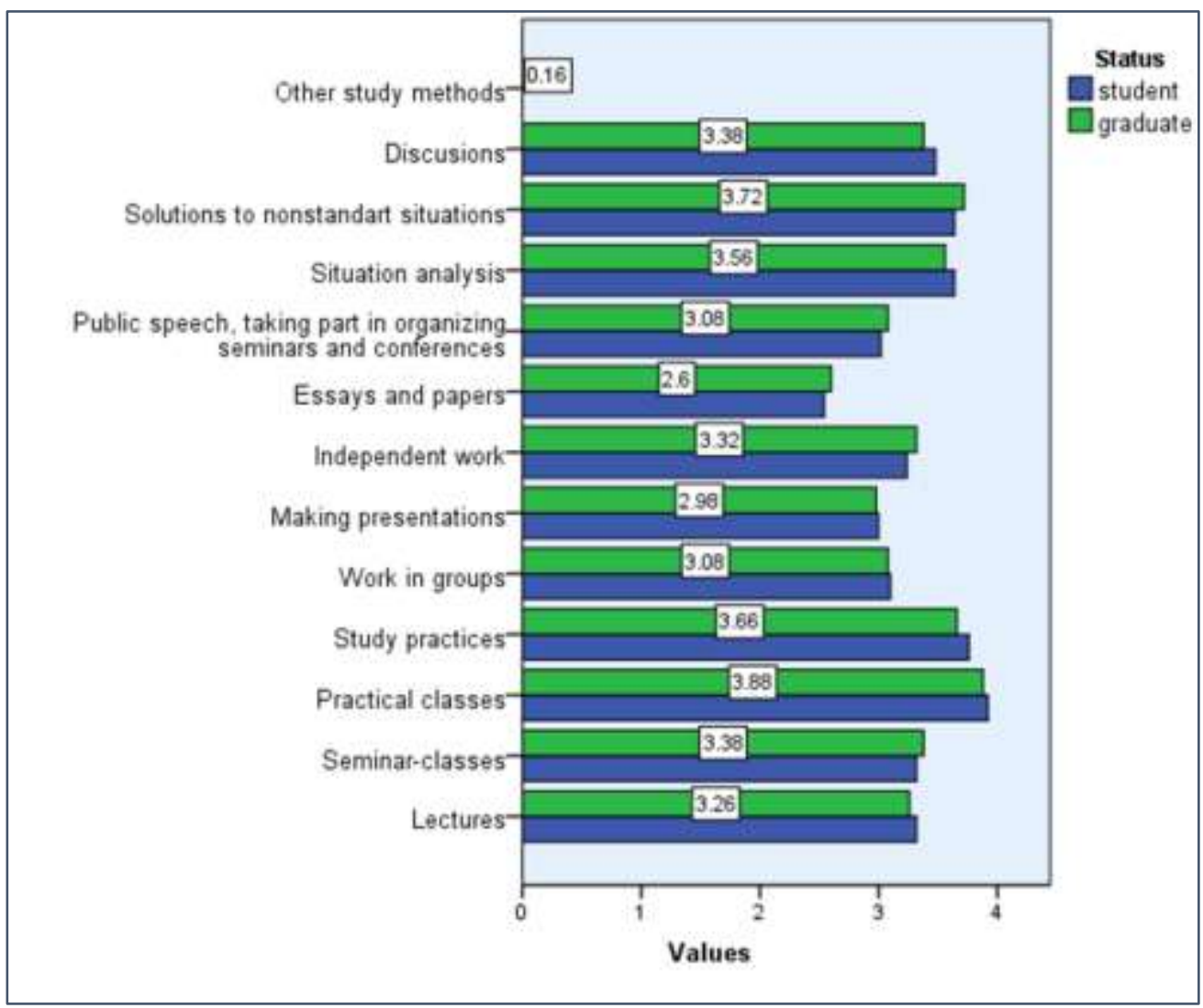

Figure 3. Teaching/Learning methods promoting the development of podologists' career management skills.

\section{Conclusions}

1. The acquisition and development of podologists' career management skills in career education in the study process is promoted by the content of the study programme ensured by practical classes, study practices and situation tasks that are purposefully organized and integrated in the study process.

2. A set of activities purposefully integrated in the study process, directed towards the development of career management skills, give an opportunity to approach the work environment already during the study process both doing the study practice and participating in practical classes and solving different non-standard clinical cases that create the sense of security and conviction in newly-qualified podologists' both to attain the immediate aims of learning - to obtain education and work, and to improve the skills of learning in the life action.

3. The formation of podologists' career management skills are determined by the individual selfdevelopment factor - the interaction between the personality's maturity and the study processthat helps in attaining the aims of professional development, self-development, new challenges and education.

4. The integration of career education in the study process ensured by the student experience-based learning approach helps to reach the aims of learning and to improve the career management skills, forming a long-term development perspective.

\section{Bibliography}

1. Amundson N.E. (2005). The potential impact of global changes in work for career theory and practice. International Journal of Educational and Vocational Guidance, 5(2), 91-99.

2. Andersone R. (2007). Citizenship Education in Integrated Curriculum. In A. Ross (Ed.), Citizenship Education in Society. London: CiCe, 136-146.

3. Anspoka Z., Kazaka D. (2017). Learning Theories in Modern Scholar Learning Aspect: Different Problems and Solution in Practice. In V. Dislere (Ed.), The Proceedings of International Scientific Conference Rural 
Environment. Education. Personality (REEP), 10, Jelgava: LLU TF, 23-29. Retrieved from http://llufb.1lu.lv/conference/REEP/2017/Latvia-Univ-Agricult-REEP-2017_proceedings.pdf

4. Barrett J. (2010). Human rights, sustainability and standing: A humanist perspective. Lower Hutt, New Zealand: The Open Polytechnic of New Zealand. Retrieved from https:/www.openpolytechnic.ac.nz/assets/Marketing/Research/Current-workingpapers/WP409Humanrightssustainabilitystanding.pdf

5. Cendon E. (2018). Connecting Theory and Practice in Higher Education in Germany. In Talbot J. (Ed.), Global Perspectives on Work-Based Learning Initiatives. Hershey: IGI Global, 84-113.

6. CEDEFOP. (2009). Professionalising Career Guidance: Practitioner Competences and Qualification Routes in Europe. Luxembourg: Office for Official Publications of the European Communities. Retrieved from http://www.cedefop.europa.eu/files/5193_en.pdf

7. Chen C.P. (2015). Career human agency theory. In K. Maree, A. Di Fabio (Eds.), Exploring New Horizons in Career Counselling. Turning Challenge into Opportunities. Rotterdam: Sense Publishers, 77-98.

8. Dauber H. (2009). Grundlagen humanistischer Padagogik: Leben lernen fur eine humane Zukunft (Basics of Humanistic Pedagogy: Life Learning for a Humane Future). (2 $2^{\text {nd }}$ ed.). Bad Heilbrunn: Klinkhardt. (in German)

9. Education Law. (2014). Riga: The Saeima of Latvia. Retrieved from https://likumi.lv/ta/en/en/id/50759

10. ELGPN. (2010). Lifelong Guidance Policies: Work in Progress. A report on the work of the European Lifelong Guidance Policy Network 2008-10. Jyvaskyla, Finland: The European Lifelong Guidance Policy Network (ELGPN). Retrieved from http://www.elgpn.eu/publications/browse-by-

language/english/european-lifelong-guidance-policies-work-in-progress.-a-report-on-the-work-of-theeuropean-lifelong-guidance-policy-network-2009201310/

11. European Commission/EACEA/Eurydice. (2014). Modernisation of Higher Education in Europe: Access, Retention and Employability 2014. Eurydice Report. Luxembourg: Publications Office of the European Union. Retrieved from

http://commit.eucen.eu/sites/commit.eucen.eu/files/Eurydice_AccRetEmpl_May2014_165EN.pdf

12. Fabry G. (2012). Didaktik der Medizin (Didactics of Medicine). In Krukemeyer M.G. (Hrsg), Aus- und Weiterbildung in der klinischen Medizin. Didaktik und Ausbildungskonzepte. Stuttgart: Schattauer, 3 - 18. (in German)

13. Heim H. (1998). Humanistische pädagogik (Humanist pedagogy). Frankfurt am Main: Peter Lang, Europascher Verlag der Wissenschaften. (in German)

14. Huitt W. (2011). Why Study Educational Psychology? Educational Psychology Interactive. Valdosta: Valdosta State University. Retrieved from http://www.edpsycinteractive.org/topics/intro/whyedpsy.html

15. Ivanova T., Saulite M., Andersone R. (2014). Podology Education in Latvia and European Union: A Comparative Study. In V.P. Karnups (Ed.), Humanities and social sciences Latvia, 22(2), 79-97. Retrieved from https://www.lu.lv/fileadmin/user_upload/lu_portal/apgads/PDF/Hum_Soc-scienc-2014_2_.pdf

16. Jackson N., Willis J. (Eds.). (2014). Lifewide Learning and Education in Universities and Colleges: Concepts and Conceptual Aids. Retrieved from http://www.learninglives.co.uk/uploads/1/0/8/4/10842717/chapter_a1.pdf

17. OECD. (2014). Skills Beyond School: Synthesis Report. OECD Reviews of Vocational Education and Training. Paris: OECD Publishing. Retrieved from https://www.oecd.org/edu/skills-beyond-school/SkillsBeyond-School-Synthesis-Report.pdf

18. Okolie U.C., Yasin A. M. (2017). Technical Education and Vocational Training in Developing Nations. Hershey: IGI Global.

19. Saulite M., Koha A. (2017). Purposeful Development of Career Management Skills in the Podologists' Study Process. In V. Dislere (Ed.), The Proceedings of the International Scientific Conference Rural Environment. Education. Personality (REEP), 10, Jelgava: LLU TF, 466-472. Retrieved from http://llufb.1lu.lv/conference/REEP/2017/Latvia-Univ-Agricult-REEP-2017_proceedings.pdf

20. Stevenson I. (2008). Tool, tutor, environment or resource: Exploring metaphors for digital technology and pedagogy using activity theory. Computers and Education, 51(2), 836-853. Retrieved from https://doi.org/10.1016/j.compedu.2007.09.001

21. Super D.E. (1963). Self-Concepts in Vocational Development. In D. Super, R. Starishevsky, N. Matlin, J. Jordan (Eds.), Career Development: Self-Concept Theory. Princeton, NJ: The College Entrance Examination Board, 17-32.

22. Talbot J. (2018). Work-Based Learning in the United Kingdom: What We Know of Practice and an Example - The WBL Module and WBIS Program at the University of Chester. In J. Talbot, (Ed.), Global Perspectives on Work-Based Learning Initiatives. Chester: University of Chester, 84-113.

23. Wells G. (Ed.). (2001). Action, Talk, and Text: Learning and Teaching through Inquiry. California: Teachers College Press. 